\title{
Effects of laser treatment on the expression of cytosolic proteins in the synovium of patients with osteoarthritis
}

\begin{tabular}{|r|l|}
\hline Journal: & Lasers in Surgery \& Medicine \\
\hline Manuscript ID: & LSM-14-0071.R1 \\
\hline Wiley - Manuscript type: & Basic Science \\
\hline Date Submitted by the Author: & n/a \\
\hline Complete List of Authors: & $\begin{array}{l}\text { Barabás, Klára; Outpatient Clinic of Budavári Local Government, Unit of } \\
\text { Rheumatology; National Institute of Rheumatology and Physiotherapy, } \\
\text { Bakos, József; "Frédéric Joliot-Curie" National Research Institute for } \\
\text { Radiobiology and Radiohygiene, Department of Non-ionizing Radiation } \\
\text { Zeitler, Zsuzsanna; "Frédéric Joliot-Curie" National Research Institute for } \\
\text { Radiobiology and Radiohygiene, Department of Non-ionizing Radiation } \\
\text { Bálint, Géza; National Institute of Rheumatology and Physiotherapy, } \\
\text { Nagy, Erzsébet; Polyclinic of the Hospitaller Brothers of St. John of God, } \\
\text { Central Laboratory } \\
\text { Lakatos, Tamás; Polyclinic of the Hospitaller Brothers of St. John of God, } \\
\text { Kékesi, Katalin; Eötvös Lorand University, Laboratory of Proteomics, } \\
\text { Institute of Biology } \\
\text { Gáspár, Lajos; Gáspár Medical Center, } \\
\text { Szekanecz, Zoltán; University of Debrecen Medical and Health Sciences } \\
\text { Center, Department of Rheumatology }\end{array}$ \\
\hline Key Words: & \begin{tabular}{l} 
ex vivo, laser therapy, proteomics, synovial membrane \\
\hline
\end{tabular} \\
\hline
\end{tabular}

\section{SCHOLARONE"}

Manuscripts 


\title{
Effects of laser treatment on the expression of cytosolic proteins in the synovium of patients with osteoarthritis
}

\author{
Klára Barabás, MD, PhD, ${ }^{1,3}$ József Bakos, $\mathrm{MSc}^{2}{ }^{2}$ Zsuzsanna Zeitler, MSc, ${ }^{2}$ Géza Bálint, MD, \\ DSc ${ }^{3}$ Erzsébet Nagy, MD, PhD, ${ }^{4}$ Tamás Lakatos, MD, PhD ${ }^{4}$ Adrienna Katalin Kékesi, \\ $\mathrm{PhD},{ }^{5,6}$ Lajos Gáspár, MD, $\mathrm{PhD},{ }^{7}$ and Zoltán Szekanecz, MD, $\mathrm{DSc}^{8}$ \\ ${ }^{1}$ Outpatient Clinic of Budavári Local Government, Unit of Rheumatology, Budapest, \\ Hungary 1122; (K B) \\ 2“Frédéric Joliot-Curie” National Research Institute for Radiobiology and Radiohygiene, \\ Budapest, Hungary 1221; (J B, Zs Z) \\ ${ }^{3}$ National Institute of Rheumatology and Physiotherapy, Budapest, Hungary 1023; (K B, G \\ B) \\ ${ }^{4}$ Polyclinic of the Hospitaller Brothers of St. John of God, Budapest, Hungary 1023; (E N, T \\ L) \\ ${ }^{5}$ Laboratory of Proteomics, Institute of Biology, Eötvös Lorand University, Budapest, \\ Hungary 1117; (AK K) \\ ${ }^{6}$ Department of Physiology and Neurobiology, Eötvös Lorand University, Budapest, \\ Hungary 1117; (AK K) \\ ${ }^{7}$ Gáspár Medical Center, Budapest, Hungary 1085; (L G) \\ ${ }^{8}$ Department of Rheumatology, University of Debrecen Medical and Health Sciences \\ Center, Debrecen, Hungary 4012; (Z Sz)
}

Grant: This work was supported by grant No 097/2009 from the Medical Research Council (ETT) of Hungary.

Corresponding author: Dr Klára Barabás, MD, PhD, National Institute of Rheumatology and Physiotherapy, Frankel Leó str 25-29, Budapest, H-1023, Hungary, phone: +36-1-326-0440, fax: + 36-1-326-0440, E-mail: drbarabasklara@gmail.com 


\begin{abstract}
Background and Objective: Low level laser therapy (LLLT) has been developed for noninvasive treatment of joint diseases. We have previously shown that LLLT influenced synovial protein expression in rheumatoid arthritis. The aim of this study was to assess the effects of laser irradiation on osteoarthritic (OA) synovial protein expression.
\end{abstract}

Study Design/Materials and methods: The synovial membrane samples removed from the knees of 6 OA patients were irradiated ex vivo using near infrared diode laser $(807-811 \mathrm{~nm}$; $25 \mathrm{~J} / \mathrm{cm}^{2}$ ). An untreated sample taken from the same patient served as control. Synovial protein separation and identification were performed by two-dimensional differential gel electrophoresis and mass spectrometry, respectively.

Results: Eleven proteins showing altered expression due to laser irradiation were identified. There were three patients whose tissue samples demonstrated a significant increase $(p<0.05)$ in mitochondrial heat shock $60 \mathrm{kD}$ protein 1 variant 1 . The expression of the other proteins (calpain small subunit 1 , tubulin alpha-1C and beta 2 , vimentin variant 3 , annexin $\mathrm{A} 1$, annexin A5, cofilin 1, transgelin and collagen type VI alpha 2 chain precursor) significantly decreased $(p<0.05)$ compared to the control samples.

Conclusions: A single diode laser irradiation of the synovial samples of patients with osteoarthritis can statistically significantly alter the expression of some proteins in vitro. These findings provide some more evidence for biological efficacy of LLLT treatment, used for osteoarthritis.

Key words: ex vivo, laser therapy, proteomics, synovial membrane 


\section{Introduction}

Studies of the expression of proteins (proteomics) play a more and more important role in the investigation of various clinical entities (1). This technique has been successfully used in studying the expression of cytosolic proteins of the synovial membranes in rheumatoid arthritis (RA), osteoarthritis (OA) and ankylosing spondylitis (AS). Differences were found in the protein expression of calgranulin A, vimentin, $\alpha$-enolase, fructose biphosphate aldolase $\mathrm{A}$ in the synovial membrane of patients with RA and AS compared to OA (2). The identification of new biological and clinical markers of inflammatory rheumatic diseases (RA, AS) opened new possibilities of further dissecting the synovial effects of low level laser therapy (LLLT) (3). Bjordal et al. (4) proved the anti-inflammatory and pain-relieving effects of LLLT in the infrared wavelength range in Achilles tendinitis in a randomized, placebo controlled study. Several authors have reported the beneficial clinical results of LLLT in OA and tendinopathy (5). In in vitro studies LLLT decreased inflammation by diminishing the production of PGE2 and by inhibiting cyclo-oxigenase 2 (6-13). Rizzi et al. (14) showed that LLLT reduced the inflammatory response induced by trauma in animals by blocking the effects of reactive oxygen species (ROS) and the activation of nuclear factor kappa B (NFkB). Bo et al. (15) also suggested the importance of proteomics in understanding disease pathogenesis in arthritides and in identifying new therapeutic targets. Finally, we have recently showed that the expression of some proteins in the rheumatoid synovial membrane significantly changed following laser irradiation (16).

In the present study we wished to determine whether the expression pattern of synovial proteins in OA would be affected by ex vivo laser irradiation.

\section{Patients and methods}

\section{Patients}

Synovial samples of six patients with knee OA, according to American College of Rheumatology (ACR) classification criteria, were studied. The clinical and laboratory characteristics of our patients are shown in Table 1.

\section{Sample preparation and protein extraction}


Following surgery, OA synovial membrane samples were immediately placed into Medium 199 (Sigma Aldrich) solution at $4{ }^{\circ} \mathrm{C}$. First the fatty and connective tissues were removed, then two $0.5 \mathrm{~cm}^{2}$ pieces from the macroscopically identical, adjacent parts of synovial membranes were excised. For the in vitro irradiation of synovial membrane samples, an approximate mean radiant exposure of $25 \mathrm{~J} / \mathrm{cm}^{2}$ was chosen to model real exposure during clinical treatment (16). Half of the samples were irradiated by laser at distance of $8 \mathrm{~cm}$ from the aperture in Petri dishes containing M199 medium. The irradiated area was about 1 $\mathrm{cm}^{2}$. The control samples were kept under identical conditions, but were not irradiated. Laser irradiation was carried out using a KLS-500 type diode laser (Laseuropa Ltd, Budapest, Hungary), a laser instrument similar to ones used in clinical practice of the authors. The parameters of the laser were as follows: wavelength: $807-811 \mathrm{~nm}$; power: $448 \mathrm{~mW}$; output aperture size: $2 \mathrm{~mm} \times 4.5 \mathrm{~mm}$; beam divergence: $5^{\circ}$. Following irradiation, the samples were incubated at $37{ }^{\circ} \mathrm{C}$ for 21 hours in M199 medium in a $5 \% \mathrm{CO}_{2}$ thermostat (Heto-Holten). The samples were stored at $-70^{\circ} \mathrm{C}$ until further use. In order to extract proteins, the frozen samples were homogenized using a homogenizer (Janke\&Kunkel Ika-Werk Ultra Turrax) on ice in 300-300 $\mu$ l lysing buffer (7 M urea, $2 \mathrm{M}$ thiourea, $30 \mathrm{mM}$ Tris, $4 \%$ CHAPS, $\mathrm{pH}$ 8.5). The solution underwent ultrasound treatment for 1 minute (Bandelin Sonorex TK52) then it was centrifuged $\left(12,000 \mathrm{~g}\right.$, one hour, $\left.4{ }^{\circ} \mathrm{C}\right)$. The proteins in the supernatant were precipitated by acetone $(1: 4 \mathrm{v} / \mathrm{v})$, then they were centrifuged $\left(3,000 \mathrm{~g}, 10\right.$ minutes, $\left.4{ }^{\circ} \mathrm{C}\right)$. The protein samples were stored in a lysing buffer at $-20{ }^{\circ} \mathrm{C}$ until analytical processing.

\section{Separation of proteins by two-dimensional differential gel electrophoresis (2D-DIGE)}

The $\mathrm{pH}$ of protein samples was set at 8.0 and then the protein concentration of the samples was determined using PlusOne Quant Kit (GE Healthcare Hungary, Budapest) according to manufacturer's protocol. From each sample, $5 \mu \mathrm{g}$ of proteins were labelled with CyDye DIGE Fluor Labelling kit for Scarce Samples (GE Healthcare) dye (4 nmol of dye / 5 $\mu \mathrm{g}$ of proteins) according to protocol. Samples containing $2.5 \mu \mathrm{g}$ of proteins from each control and each laser-treated sample got into the pooled (internal standard) sample. This pooled sample was labelled by $\mathrm{Cy} 3$, whereas the control and the treated samples were labelled by Cy5. Then the two differently labelled samples ( $5 \mu \mathrm{g}$ of samples and $5 \mu \mathrm{g}$ of pooled samples labelled by $\mathrm{Cy} 5$ and Cy3, respectively) were mixed. Next, $2 \mathrm{mg} / \mathrm{ml}$ ditio-treitol (DTT) and 5 $\mu \mathrm{l} / \mathrm{ml}$ of IPG buffer were added fresh to our buffer ( $8 \mathrm{M}$ of urea, $4 \mathrm{v} / \mathrm{v} \%$ of CHAPS, $15 \mathrm{v} / \mathrm{v} \%$ 
of glycerine), the mixed samples were completed to $450 \mu$ l. The samples were then rehydrated on $24 \mathrm{~cm}$ IPG strips ( $\mathrm{pH}$ 3-10 NL, GE Healthcare) for 14 hours at room temperature. Rehydration was followed by the isoelectric focusing of the proteins for 23.5 hours using Multiphore II (GE Healthcare) equipment. The settings were the same as reported previously (16). After this the focused proteins were reduced with / in an equilibrated solution for 20 minutes $(1.5 \mathrm{M}$ of Tris, $6 \mathrm{M}$ of urea, $30 \%$ of glycerine, $20 \%$ of sodium dodecyl sulphate (SDS), $0.1 \%$ of bromide-phenol blue, $1 \mu \mathrm{l} / \mathrm{ml}$ of mercaptoethanol), then the strips were placed on SDS polyacrylamid gels of $10 \%$ and were fitted with agar solution of $0.5 \%$. The gels were run in running tubs filled up with running buffers (Ettan Dalt Six, GE Healthcare) with of the following parameters: 60 minutes, $18{ }^{\circ} \mathrm{C}, 2 \mathrm{~W} / \mathrm{gel}$; then: 6 hours, $18{ }^{\circ} \mathrm{C}, 12 \mathrm{~W} / \mathrm{gel}$. At the end of running the gels were scanned by Typhoon TRIO + device at a wavelength corresponding with the applied CyDye dyes. The scanned pictures were evaluated with the DIA (DeCyder Differential Image Analysis) and BVA (DeCyder Biological Variation Analysis) programs. The protein spots were identified in which the amount of proteins were significantly different $(\mathrm{p}<0.05)$ in the treated sample compared to the control.

\section{Protein identification using preparative gel and data analysis}

Protein samples of $800 \mu \mathrm{g}$ were added to the preparative gel. During the first dimensional run the protocol corresponding to the analytical gel was applied. Deviation occurred just at the second dimensional run. The glass sheets used for preparing the gel had been treated with Blind Silane solution (ethanol: $80 \%$, ice vinegar acid: $0.02 \%$, blind silane: $0.001 \%$, ddw: $18 \%$ ). After the run, the gels were fixed for an hour (20\% of methanol, $1 \%$ of phosphoric acid), then they were dyed using methanol:A:B=2:8:1 solution. (Solution A: 0.3 $\mathrm{M}$ of ammonium-sulphate, $2.4 \%$ of phosphoric acid; solution B: $5 \%$ of Coomassie Blue G250) for one week. Then gels were neutralized using Tris-solution of $0.05 \mathrm{M}$ (pH 6.5) for 3 minutes, then it was washed with methanol of $25 \%$, finally it was stabilized by ammoniumsulphate of $0.75 \mathrm{M}$ for 8 hours. Based on the results of the analytical gel, the identical protein spots of the preparative gel were excised. These were evaluated in the Department of Chemistry at University of Szeged by liquid chromatography-mass spectrometry (LCMS/MS) analysis. For the identification of proteins the following criteria were used: protein score $>66$ (see Table 2 ) and level of significance of $p<0.05$ were considered as significant.

\section{Results}


Altogether 11 proteins exerted differential expression in LLLT reated OA synovial tissue samples as compared to untreated control samples (Table 2).

Mitochondrial heat-shock $60 \mathrm{kD}$ protein 1 variant 1 (mhsp60) was the only protein showing significantly increased expression in synovial tissue of three patients following LLLT compared to untreated synovial tissue $(\mathrm{p}<0.05)$.

Other synovial proteins, such as calpain small subunit 1 , tubulin alpha-1C and beta 2 , vimentin variant 3, annexin A1, annexin A5, cofilin 1, transgelin and collagen type VI alpha 2 chain precursor exerted significantly lower expression in OA synovium of at least three patients following LLLT as compared to controls $(\mathrm{p}<0.05)$ (Table 3$)$.

\section{Discussion}

The clinical efficacy of LLLT in various arthritides including OA has been established. However, little is known about the exact molecular effects of laser irradiation. Some research groups have used gel electrophoresis and MS proteomic techniques to compare the composition of healthy and OA cartilage. Garcia et al. (17) studied the components of OA chondrocytes and extracellular matrix (ECM) by MS method. Several proteins involved in ECM organisation, signal transduction, cell communication, immune responses and metabolism showed differential expression. Kirsch et al. (18) showed the expression of alkaline phosphatase, annexin II and type VI type collagen in the upper zone chondrocytes of human OA cartilage, but none of these in healthy human cartilage.

Here we present only those proteins that exerted significantly increased or decreased expression upon LLLT.

Our results show increased expression of mhsp60 in OA synovial membrane after LLLT compared to untreated controls. This protein belongs to the hsp60 (chaperonin) family (19-21). Tsan et al. (22) consider hsp-s as molecular chaperons recognizing and bounding polypeptid chains, and the partly-folded intermediates of proteins. Hsp-s inhibit aggregation, erroneous folding and directly mediate protein folding as chaperons. Yokota et al. (23) showed that anti-hsp60 antibody levels are higher in autoimmune diseases, such as rheumatoid arthritis, SLE, Sjögren's syndrome and mixed connective tissue disease compared to healthy controls. Sedlackova et al. (24) suggested that the expression profile of hsp60 gene might serve as a new marker in the differential diagnosis between RA and OA. Hsp gene 
expression profiles may be very different in inflammatory (RA) and non-inflammatory (OA) joint diseases.

Some other proteins showing diminished synovial expression after LLLT including calpain small subunit 1 . This is a calcium-dependent cystein protease formed in the cartilage and synovial tissue. RA and OA chondrocytes actively secrete calpain and calpain levels are increased in both RA and OA synovial fluids compared to normal controls $(25,26)$. Whiteman et al. (27), as well as Squier et al. (28) described peroxynitrite (ONOO-)-mediated, calcium-dependent mitochondrial dysfunction and apoptosis caused by calpain activation. Szomor et al. (29) found that in murine collagen-induced arthritis (CIA) calpain expression correlated with the severity of inflammation and cartilage destruction. In an early phase of CIA calpain acts as a matrix proteinase and plays a role in enzyme activation and cartilage destruction. Although calpain is regarded as an intraarticular enzyme, recently calpain has also been detected in the site of callus formation after the fracture of growing cartilage (30), as well as in synovial fluids of OA patients (31). Solau-Gervais et al. (32) compared the activities of cystein proteases and dipeptidyl peptidase in synovial tissues of RA, OA and posttraumatic arthritic patients. Calpain activity was higher in RA and OA compared to posttraumatic controls. Struglics et al. (33) suggest that calpain plays a role in the cleavage of human aggrecan. Calpain-generated fragments were detected in both normal and OA cartilage and synovial fluids. Iguchi-Hashimoto et al. (34) described the overexpression of calpastatin, a calpain antagonist in arthritis. Calpastatin supresses IL-6 production, as well as NFKB signalling in RA. As calpain is highly involved in cartilage destruction and its expression decreased by laser irradiation, thus LLLT may diminish calpain-mediated degradation in OA.

Actin and tubulin are cytoskeletal proteins. Tubulin is a member of the family of globular proteins and is a constituent of microtubules. The expression of $\alpha$-tubulin significantly decreased in all synovial tissue samples following LLLT. Ramos-Ruiz et al. (35) found suppressed tubulin synthesis in the synoviocytes of rats with adjuvant arthritis. The inhibition of tubulin synthesis may be an initial step in the development of adjuvant arthritis.

The expression of cofilin was also reduced by LLLT in two synovial samples in our study. Campbell et al. (36) found that cofilin expression was significantly upregulated in chondrocytes upon mechanical stress. Rollin et al. (37) performed differential proteomic investigation of chondrocytes in OA patients. The expression of cytoskeletal binding proteins including cofilin and annexin 2 significantly increased in OA chondrocytes. Blain et al. (38) described a 3-dimensional network of cytoskeletal tubulin and intermediate filaments. Tubulin 
and cofilin are involved in cytoskeleton formation and also in remodelling and mechanical properties of the cartilage.

Vimentin variant 3 expression was significantly reduced after LLLT in the synovial samples of three OA patients. Haudenschild et al. (39) reported that the changes in the organisation of vimentin correlates with the progression of OA, but the results of these changes, especially in chondrocytes are not clear. In their differential proteomic analysis of normal and OA chondrocytes, Lambrecht et al. (40) discovered that the vimentin network is severely impaired in OA. The organization of split vimentin was described in OA chondrocytes. Tilleman et al. (41) studied the cleavage of a citrullinated vimentin isoforms in OA cartilage. Similarly to Haudenschild et al. (39), this group found that the disruption of vimentin network weakened the mechanical integrity of cells. Wang et al. (42) observed that in numerous cell types, the loss of vimentin led to impaired DNA synthesis and cell proliferation. Tilleman et al. (43) concluded: „It could be possible, that a higher expression of vimentin contributes to the invasive character of the synovial pannus like tissue in inflammatory arthritides". Therefore we may suppose, that laser induced decrease of vimentin variant 3 could be antiinflammatory and therefore beneficial in OA.

Ea et al. (44) reviewed the role of annexin A5 in OA. Biphasic calcium phosphate (BCP) and hydroxy-apatite (HA) crystals are associated with severe forms of OA. In severe $\mathrm{OA}$, chondrocyte apoptosis is associated with the overexpression of annexin $\mathrm{V}$ and $\mathrm{BCP}$ crystal deposition in the matrix. It was demonstrated that the overexpression of annexin $\mathrm{V}$ may contribute to hypocellularity of the articular cartilage. The reduction of annexin $\mathrm{V}$ expression by LLLT treatment may lead to decreased chondrocyte apoptosis in OA.

We observed a significant decrease in the expression of collagen type VI alpha 2 chain precursor in five OA synovial samples following laser treatment. Hambach et al. (45) demonstrated severe abnormalities in the expression and distribution of pericellular collagen VI in OA. When comparing healthy and OA cartilage, the three chains of collagen VI were abundantly expressed in healthy articular cartilage, while collagen VI expression was significantly reduced in the superficial layer of the cartilage in OA. The authors concluded that the underexpression of collagen VI in the cartilage may result from increased degradation rather than by a decreased synthetic activity. Murray et al. (46) suggested that in OA the disruption of pericellular collagen VI was associated with increased production of IL-1 $\beta$. Thus, the decrease in collagen VI expression induced by LLLT might be advantageous regarding chondrocyte metabolism. 
1

2

3

4

5

6

7

8

9

10

11

12

13

14

15

16

17

18

19

20

21

22

23

24

25

26

27

28

29

30

31

32

33

34

35

36

37

38

39

40

41

42

43

44

45

46

47

48

49

50

51

52

53

54

55

56

57

58

59

60

In conclusion, the significant increase in the expression of mhsp60 after LLLT treatment of OA synovial samples suggests the existence of a reparation process that inhibits protein aggregations and protein misfolding. The decreased expression of calpain small subunit 1, annexin A5, vimentin variant 3 and collagen type VI alpha 2 chain precursor expression after LLLT may result in the suppression of cartilage degradation in OA. Our study provided additional evidence for the molecular effects of LLLT in rheumatic diseases. 


\section{References}

1 Anderson, NL, Anderson, NG. The human plasma proteome. Mol Cell Proteomics 2002; 1:845-267.

2 Sinz A, Bantscheff M, Mikkat S, Ringel B, Drynda S, Kekow J, et al. Mass spectrometric proteome analyses of synovial fluids and plasmas from patients suffering from rheumatoid arthritis and comparison to reactive arthritis or osteoarthritis. Electrophoresis 2002; 23:3445-3456.

3 Smolen JS, Aletaha D, Grisar J, Redlich K, Steiner G, Wagner O. The need for prognosticators in rheumatoid arthritis Biological and clinical markers where are we now? Arthritis Res Ther 2008; 10:208.

4 Bjordal JM, Lopes-Martins RA, Iversen VV. A randomised, placebo controlled trial of low level laser therapy for activated Achilles tendinitis with microdialysis measurement of peritendinous prostaglandin E2 concentrations. Br J Sports Med 2006; 40:76-80.

5 Bjordal J, Couppé C, Ljunggreen A. Low level laser therapy for tendinopathy Evidence of a dose response pattern. Phys Ther Rev 2001; 6:91-99.

6 Bjordal J, Couppé C, Chow RT, Tunér J, Ljunggren EA. A systematic review of low level laser therapy with location-specific doses for pain from chronic joint disorders. Aust J Physiother 2003; 49:107-116.

7 Loevschall H, Arenholt-Bindslev D. Effect of low level diode laser irradiation of human oral mucosa fibroblasts in vitro. Lasers Surg Med 1994; 14:347-354.

8 Pereira AN, Eduardo CP, Matson E, Marques MM. Effect of low power laser irradiation on cell growth and procollagen synthesis of cultured fibroblasts. Lasers Surg Med 2002; 31:263-267.

9 Almeida-Lopes L, Rigau J, Zângaro RA, Guidugli-Neto J, Jaeger MM. Comparison of the low level laser therapy effects on cultured human gingival fibroblasts proliferation using different irradiance and same fluence. Lasers Surg Med 2001; 29:179-184.

10 Reddy GK, Stehno BL, Enwemeka CS. Laser photostimulation of collagen production in healing rabbit achilles tendon. Lasers Surg Med 1998; 22:281-287.

$11 \mathrm{Yu}$ W, Naim JO, Lanzafame RJ. Effects of photostimulation on wound healing in diabetic mice. Lasers Surg Med 1997; 20:56-63.

12 Honmura A, Ishii A, Yanase M, Obata J, Haruki E. Analgesic effect of GaAlAs diode laser irradiation on hyperalgesia in carrageenin induced inflammation. Lasers Surg Med 1993; 13:463-469.

13 Sakurai Y, Yamaguchi M, Abiko Y. Inhibitory effect of low level laser irradiation on LPS stimulated prostaglandin E2 production and cyclooxygenase 2 in human gingival fibroblasts. Eur J Oral Sci 2000; 10:829-34.

14 Rizzi CF, Mauriz JL, Freitas Corrêa DS, Moreira AJ, Zettler CG, Filippin LI, Marroni NP, González-Gallego J. Effects of low level laser therapy (LLLT) on the nuclear factor (NF)-kappaB signaling pathway in traumatized muscle. Laser Surg Med 2006; 38:704-713.

15 Bo GP, Zhou LN, He WF, Luo GX, Jia XF, Gan CJ, Chen GX, Fang YF, Larsen PM, $\mathrm{Wu} \mathrm{J}$. Analyses of differential proteome of human synovial fibroblasts obtained from arthritis. Clin Rheumatol 2009; 28:191-199.

16 Bálint G, Barabás K, Zeitler Zs, Bakos J, Kékesi KA, Pethes Á, Nagy E, Lakatos T, Tanos E, Bálint P, Szekanecz Z. Ex Vivo Soft-Laser Treatment Inhibits the Synovial Expression of Vimentin and $\alpha$-Enolase, Potential Autoantigens in Rheumatoid Arthritis. Phys Ther 2011; 91:665-674. 
17 Garcia BA, Platt MD, Born TL, Shabanowitz J, Marcus NA, Hunt DF. Protein profile of osteoarthritic human articular cartilage using tandem mass spectrometry. Rapid Commun Mass Spectrom 2006; 20:2999-3006.

18 Kirsch T, Swoboda B, Nah HD. Activation of annexin II and V expression, terminal differentiation, mineralization and apoptosis in human osteoarthritic cartilage. Osteoarhtritis Cartilage 2000; 8:294-302.

19 Fink AL. Chaperone-mediated protein folding. Physiol Rev 1999; 79:425-449.

20 Hartl FU, Hayer-Hartl M. Molecular chaperones in the cytosol from nascent chain to folded protein. Science 2002; 295:1852-1858.

21 Lindquist S, Craig EA. The heat-shock proteins. Annu Rev Genet 1988; 22:631-677.

22 Tsan MF, Gao B. Cytokine function of heat shock proteins. Am J Physiol 2004; 286:C739-C744.

23 Yokota S, Hirata D, Minota S, Higashiyama T, Kurimoto M, Yanagi H, Yura T, Kubota H. Autoantibodies against chaperonin CCT in human sera with rheumatic autoimmune diseases comparison with antibodies against other Hsp60 family proteins. Cell Stress Chaperones 2000; 5:337-346.

24 Sedlackova L, Sosna A, Vavrincova P, Frýdl J, Guerriero V, Raynes DA, Hromadnikova I. Heat shock protein gene expression profile may differentiate between rheumatoid arthritis, osteoarthritis and healthy controlls. Scand J Rheumatol 2011; 40:354-357.

25 Yamamoto S, Shimizu K, Shimizu K, Suzuki K, Nakagawa Y, Yamamuro T. Calcium-dependent cysteine proteinase (calpain) in human arthritic synovial joints. Arthritis Rheum 1992; 35:1309-1317.

26 Suzuki K, Shimizu K, Hamamoto T, Nakagawa Y, Hamakubo T, Yamamuro T. Biochemical demonstration of calpains and calpastatin in osteoarthritic synovialfluid. Arthritis Rheum 1990; 33:728-732.

27 Whiteman M, Armstrong JS, Cheung NS, Siau JL, Rose P, Schantz JT, Jones DP, Halliwell B. Peroxynitrite mediates calcium-dependent mitochondrial dysfunction and cell death via activation of calpains. Faseb J 2004; 18:1395-1397.

28 Squier MK, Miller AC, Malkinson AM, Cohen JJ. Calpain activation in apoptosis. $J$ Cell Physiol 1994; 159:229-237.

29 Szomor Z, Shimizu K, Fujimori Y, Yamamoto S, Yamamuro T. Appearance of calpain correlates with arthritis and cartilage destruction in collagen induced arthritic knee joints of mice. Ann Rheum Dis 1995; 54:477-483.

30 Nakagawa Y, Shimizu K, Hamamoto T, Suzuki K, Ueda M, Yamamuro T. Calcium dependent proteinase (calpain) in fracture healing in rats. J Orthop Res 1994; 12:5869.

31 Fukui I, Tanaka K, Murachi T Extracellular appearance of calpain and calpastatin in the synovial fluid of the knee joint Biochem Biophys Res Commun 1989; 162559-66

32 Solau-Gervais E, Zerimech F, Lemaire R, Fontaine C, Huet G, Flipo RM Cysteine and serine proteases of synovial tissue in rheumatoid arthritis and osteoarthritis. Scand $J$ Rheumatol 2007; 36 (5)373-7

33 Struglics A, Hansson M Calpain is involved in C-terminal truncation of human aggrecan. Biochem J $2010430531-8$

34 Iguchi-Hashimoto M, Usui T, Yoshifuji H, Shimizu M, Kobayashi S, Ito Y, Murakami K, Shiomi A, Yukawa N, Kawabata D, Nojima T, Ohmura K, Fujii T, Mimori T. Overexpression of a domain of calpastatin suppress IL-6 production and Th15 development via reduced NF-kB and increased STAT5 Signals. PloS One 2011; 6:e27020. 
35 Ramos-Ruiz R, Avila J, López-Bote JP, Bernabeu C, Larraga V. Decreased tubulin synthesis in synoviocytes from adjuvant-induced arthritic rats. Biochim Biophys Acta 1992; 1138:184-190.

36 Campbell JJ, Blain EJ, Chowdhury TT, Knight MM. Loading alters actin dynamics and up-regulates cofilin gene expression in chondrocytes. Biochem Biophys Res Commun 2007; 361:329-334.

37 Rollín R, Tornero P, Marco F, Camafeita E, Calvo E, López-Durán L, Jover JÁ, López JA, Lamas JR, Fernández-Gutiérrez B. Differential proteome of articular chondrocytes from patients with osteoarthritis. J Proteomics Bioinform 2008; 1:267-280.

38 Blain EJ. Involvement of the cytoskeletal elements in articular cartilage homeostasis and pathology. Int J Exp Pathol 2009; 90:1-15.

39 Haudenschild DR, Chen J, Pang N, Steklov N, Grogan SP, Lotz MK, D'Lima DD. Vimentin contributes to changes in chondrocyte stiffness in osteoarthritis. J Orhop Res 2011, 29:20-25.

40 Lambrecht S, Verbruggen G, Verdonk PC, Elewaut D, Deforce D. Differential proteome analysis of normal and osteoarthritic chondrocytes reveals distortion of vimentin network in osteoarhtritis. Osteoarhtritis Cartilage 2008; 16:163-173.

41 Tilleman K, Deforce D, Elewaut D. Rheumatology a close encounter with proteomics. Rheumatology 2005; 44:1217-1226.

42 Wang N, Stamenovic D. Contribution of intermediate filaments to cell stiffness, stiffening and growth. Am J Physiol Cell Physiol 2000; 279:C188-194.

43 Tilleman K, Van Beneden K, Dhondt A, Hoffman I, De Keyser F, Veys E, Elewaut D, Deforce D. Chronically inflamed synovium from spondyloarthropathy and rheumatoid arthritis investigated by protein expression profiling followed by tandem mass spectrometry. Proteomics 2005; 5:2247-2257.

44 Ea HK, Monceau V, Camors E, Cohen-Solal M, Charlemagne D, Lioté F. Annexin 5 overexpression increased articular chondrocyte apoptosis induced by basic calcium phosphate crystals. Ann Rheum Dis 2008; 67:1617-1625.

45 Hambach L, Neureiter D, Zeiler G, Kirchner T, Aigner T. Severe disturbance of the distribution and expression of type VI collagen chains in osteoarthritic articular cartilage. Arthritis and Rheumatism 1998; 6:986-996.

46 Murray DH, Bush PG, Brenkel IJ, Hall AC. Abnormal human chondrocyte morphology is related to increased levels of cell-associated il-1ß and disruption to pericellular collagen type VI. J Orthop Res 2010; 28:1507-1510. 
1

2

3

4

5

6

7

8

9

10

11

12

13

14

15

16

17

18

19

20

21

22

23

24

25

26

27

28

29

30

31

32

33

34

35

36

37

38

39

40

41

42

43

44

45

46

47

48

49

50

51

52

53

54

55

56

57

58

59

60

Table 1 Clinical and laboratory parameters of our patients

\begin{tabular}{|c|c|c|c|}
\hline Patient No. & Age (years) & $\begin{array}{c}\text { Disease } \\
\text { duration (years) }\end{array}$ & NSAID treatment \\
\hline 1 & 76 & 5 & + \\
\hline 2 & 54 & 4 & + \\
\hline 3 & 74 & 5 & + \\
\hline 4 & 73 & 20 & + \\
\hline 5 & 57 & 3 & - \\
\hline 6 & 79 & 5 & + \\
\hline
\end{tabular}

John Wiley \& Sons, Inc. 
Table 2 Proteins showing significantly altered synovial expression upon laser irradiation

\begin{tabular}{|c|c|c|l|l|}
\hline $\begin{array}{c}\text { Identification } \\
\text { number of spot }\end{array}$ & $\begin{array}{c}\text { Score of } \\
\text { protein shots }\end{array}$ & $\begin{array}{c}\text { Mass of protein } \\
\text { molecule (kDa) }\end{array}$ & NCBI ID* & Identified protein \\
\hline 1830 & 144 & 28 & 4502565 & $\begin{array}{l}\text { calpain small } \\
\text { subunit 1 }\end{array}$ \\
\hline 1100 & 132 & 61 & 189502784 & $\begin{array}{l}\text { mitochondrial heat } \\
\text { shock 60kD } \\
\text { protein 1 variant 1 }\end{array}$ \\
\hline 1486 & 94 & 37 & 21619816 & tubulin alpha-1C \\
\hline 1599 & 192 & 50 & 5174735 & $\begin{array}{l}\text { tubulin beta 2 } \\
\text { vimentin variant 3 }\end{array}$ \\
\hline 1803 & 150 & 50 & 167887751 & annexin A1 \\
\hline 1655 & 92 & 39 & 4502101 & annexin A5 \\
\hline 1923 & 96 & 36 & 49168528 & $\begin{array}{l}\text { cofilin 1 } \\
\text { transgelin }\end{array}$ \\
\hline 581 & 94 & 19 & 5031635 & $\begin{array}{l}\text { collagen type VI } \\
\text { alpha 2 chain } \\
\text { precursor }\end{array}$ \\
\hline
\end{tabular}

(* National Center for Biotechnology Information, identification number of the protein at the National Center for Biotechnology (USA)) 
Table 3 Treated/untreated expression rates of synovial proteins

\begin{tabular}{|c|c|c|c|c|}
\hline $\begin{array}{c}\text { Identification } \\
\text { number of spot }\end{array}$ & $\begin{array}{l}\text { Name of } \\
\text { protein }\end{array}$ & $\begin{array}{c}\text { Identification } \\
\text { number of } \\
\text { patients* }\end{array}$ & $\begin{array}{c}\text { Rate of treated / } \\
\text { control }\end{array}$ & $\begin{array}{c}\text { Average of } \\
\text { rates }\end{array}$ \\
\hline 1830 & $\begin{array}{l}\text { calpain small } \\
\text { subunit } 1\end{array}$ & $\begin{array}{l}4 \\
2 \\
1\end{array}$ & $\begin{array}{l}0.78 \\
0.79 \\
0.67\end{array}$ & 0.75 \\
\hline 1100 & $\begin{array}{l}\text { mitochondrial } \\
\text { heat shock } 60 \mathrm{kD} \\
\text { protein } 1 \text { variant } \\
1\end{array}$ & $\begin{array}{l}2 \\
3 \\
5\end{array}$ & $\begin{array}{l}6.31 \\
2.00 \\
2.99\end{array}$ & 3.77 \\
\hline 1486 & tubulin alpha-1C & $\begin{array}{l}6 \\
5 \\
4 \\
3 \\
2 \\
1\end{array}$ & $\begin{array}{l}0.92 \\
0.87 \\
1.02 \\
0.94 \\
0.84 \\
0.72 \\
\end{array}$ & 0.88 \\
\hline 1599 & \begin{tabular}{|l} 
tubulin beta 2 \\
vimentin variant \\
3
\end{tabular} & $\begin{array}{l}5 \\
3 \\
2 \\
\end{array}$ & $\begin{array}{l}0.58 \\
0.11 \\
0.09 \\
\end{array}$ & 0.26 \\
\hline 1803 & annexin A1 & $\begin{array}{r}5 \\
2 \\
6 \\
3 \\
1 \\
\end{array}$ & $\begin{array}{l}0.89 \\
0.90 \\
0.78 \\
0.81 \\
0.87\end{array}$ & 0.85 \\
\hline 1655 & annexin A5 & $\begin{array}{l}2 \\
3 \\
1 \\
4\end{array}$ & $\begin{array}{l}0.85 \\
0.58 \\
0.75 \\
0.76\end{array}$ & 0.74 \\
\hline 1923 & $\begin{array}{l}\text { cofilin 1 } \\
\text { transgelin }\end{array}$ & $\begin{array}{l}2 \\
3 \\
\end{array}$ & $\begin{array}{r}0.74 \\
0.78 \\
\end{array}$ & 0.76 \\
\hline 581 & $\begin{array}{l}\text { collagen type VI } \\
\text { alpha } 2 \text { chain } \\
\text { precursor }\end{array}$ & $\begin{array}{l}1 \\
5 \\
3 \\
2 \\
6\end{array}$ & $\begin{array}{l}0.82 \\
0.71 \\
0.77 \\
0.60 \\
0.72 \\
\end{array}$ & 0.72 \\
\hline
\end{tabular}

* Only those patients are indicated in whom there was a significant change $(\mathrm{p}<0.05)$ upon laser irradiation . 